\title{
Educational intervention and HIV infection: preliminary results
}

\author{
Sylvie Bregigeon, Brigitte Canet, Véronique Obry-Roguet, Amélie Menard, Isabelle Poizot-Martin* \\ From $16^{\text {th }}$ International Symposium on HIV and Emerging Infectious Diseases \\ Marseille, France. 24-26 March 2010
}

\section{Background}

To describe demographical, socio-behavioral and clinical characteristics of HIV Infected Patients included in a educational intervention program (EIP).

\section{Methods}

We initiated in March 2009 an EIP in an HIV outdoor Clinical Unit witch follow about 1000 HIV infected patients with $40 \%$ HCV coinfected. This program included at last 3 educational consultations for each patient (at least 2 initial educational consultations permitted to do a personal educational diagnosis and to fix objectives with patients and at least 1 follow up educational consultation to validate experiences) and was performed by a specifically training nurse. This analysis focused on quality of life with a self administered questionnaire at inclusion in the program.

\section{Results}

Up to now, the EIP has been proposed to 68 patients HIV infected by physicians (73.6\%), by nurses (22.6\%) and during pluridisciplinary staff (3.8\%). 53 patients (79\%) have been included (45.3\% females, median age: 43.9 years, median HIV follow up: 13.9 years, median cART exposition: 11.8 years, median CD4 Cell Count/ mm3: 324, and median plasma HIV viral load copies Log/ml: 1.87 ) in 22 cases for bad adherence, in 22 cases for initiation or changing therapy, in 7 cases for HIV positive diagnosis and in 2 cases for virological failure.

At 31/10/2009, 160 educational consultations were realized, that is to say 3,02 consultations/patient over 8 months (mean duration of session $=45 \mathrm{~min}$ ). The dates (meetings) were respected by $79 \%$ of patients and the self-administered questionnaires were all filled.

\footnotetext{
* Correspondence: isabelle.poizot@mail.ap-hm.fr

Department of Immuno-hematology, HIV-Clinical center, Hospital

SainteMarguerite, Marseilles, France
}

Amoung the 53 patients, $81,1 \%$ live alone and $42,8 \%$ have precarious situation. Vulnerability/Stress factor and handicap was found in respectively $73.3 \%$ and $46.3 \%$. A bad knowledge of HIV infection and therapy was found in respectively $32.3 \%$ and $41.9 \%$. Near of $20 \%$ declared to have unprotected sexual behavior.

We found a correlation between the level of knowledge of HIV infection or treatment and quality of life.

\section{Discussion}

These preliminary results stress the need of such program in HIV Clinical Unit.

Published: 11 May 2010

doi:10.1186/1742-4690-7-S1-P92

Cite this article as: Bregigeon et al.: Educational intervention and HIV infection: preliminary results. Retrovirology 2010 7(Suppl 1):P92.

\section{Submit your next manuscript to BioMed Central and take full advantage of: \\ - Convenient online submission \\ - Thorough peer review \\ - No space constraints or color figure charges \\ - Immediate publication on acceptance \\ - Inclusion in PubMed, CAS, Scopus and Google Scholar \\ - Research which is freely available for redistribution \\ Submit your manuscript at www.biomedcentral.com/submit}

